Ann. Biol. anim. Bioch. Biophys., 1978, 18 (4), 1089-1099.

\title{
Cryopreservation of gametes and embryos of salmonid fishes
}

\author{
par Susan R. ZELL \\ with the technical assistance of $M$. H. BAMFORD
}

Department of Zoology, University of Maine.

Orono, ME 04473, USA

Summary. After incubation in a Tris-citrate diluent ( $\mathrm{pH} \mathrm{8.9),} \mathrm{two-day} \mathrm{old} \mathrm{rainbow} \mathrm{trout}$ milt increased its fertility from 7 and 13 p. 100 to 78 and 79 p. 100 (equal to fresh milt). Atlantic salmon milt, frozen to $-8^{\circ} \mathrm{C}$, retained fertility of 84 and $94 \mathrm{p} .100$. After storage at - $196^{\circ} \mathrm{C}$, spermatozoa were motile but not fertile, probably due to osmotic pressure in one diluent and the extender in another. Vacuum-dried spermatozoa have been fertile, but the drying method needs refinement. Salmonid eggs and embryos survived freezing to $-55^{\circ} \mathrm{C}$ when frozen immediately after fertilization in salt solution or after eying. Frozen eggs $\left(-20^{\circ} \mathrm{C}\right)$ were fertilized after thawing.

Practical techniques for long or short-term storage of fish gametes and embryos would contribute to increased productivity in aquaculture. Several techniques have been published on cryopreservation of salmonid spermatozoa (Hodgins and Ridgway, 1964 ; Hoyle and Idler, 1968 ; Ott and Horton, 1971), but they have not generally been successful when repeated (Zell, 1974 ; Graham and Holtz, 1977, personal communication). In some cases an inadequate criterion such as motility, which was used initially to evaluate sperm fertility, could explain the lack of reproductibility. In some cases variations in sperm quality might account for the observed discrepancies. In other cases there are no explanations.

Some diluents used to protect sperm from mechanical damage during freezing, will reduce sperm fertility. For example, solutions with $\mathrm{K}^{+}$concentrations close to zero activate salmonid sperm, which then irreversibly lose their fertility (Billard and Jalabert, 1974 ; Zell, unpublished). On the other hand, some solutions improve sperm fertility. In one experiment presented in this paper, the fertility of rainbow trout milt after two days storage at $0^{\circ} \mathrm{C}$ was 7 and 12 p. 100 . Incubation for $20 \mathrm{~min}$. at $8{ }^{\circ} \mathrm{C}$ increased the fertility to 78 and 79 p. 100 equal to that of fresh milt.

In contrast to the numerous studies on fish sperm cryopreservation, only one unsuccessful attempt (Blaxter, 1953) has been published on the cryopreservation of fish eggs or embryos. However several studies demonstrating the effect diluents can have on salmonid eggs (Billard et al., 1974 ; Ginsburg, 1963 and Szöllösi and Billard, 1974) have provided data necessary to attempt freezing experiments. In addition, the survival of mammalian embryos after storage in liquid nitrogen (Leibo, 1977 ; Whittingham ef al., 1972) has illustrated the possibility of preserving vertebrate embryos.

Reprint requests to : Dr S. R. ZELL, 1408 Maple Grove Road, Duluth, Minnesota 55811, USA. 
In this paper experiments are summarized that (1) test various protocols for preserving salmonid spermatozoa (2) identify experimental variables that most critically affect spermatozoan survival and fertility during cryopreservation and (3) develop techniques for cryopreserving salmonid eggs and embryos.

\section{Material and methods.}

Gametes from brook trout (Salvelinus fontinalis), rainbow trout (Salmo gairdneri) and both sea-run and land-locked Atlantic salmon (Salmo salar) were used. Gametes were collected either at the peak or end of a spawning season, depending on when they could be provided by the hatchery. Milt was obtained by stripping several unanesthetized, ripe males. It was mixed before use, and eggs from at least two females were combined. Eggs were fertilized by the dry method or, for experiments in which unfertilized eggs or zygotes were to be frozen, they were fertilized in a Hanks' (1X) salt solution (HSS) (see table 1). About $0.5 \mathrm{ml}$ of milt was added to each sample of approximately 250-1 850 eggs. Fertility was measured as the percentage of eggs that either hatched or developed to the eyed stages. After eying, eggs from control samples were used in freezing experiments.

Media. - The media used are shown in table 1. All Hanks' media were prepared from a commercial solution of Hanks' (10X) balanced salt solution (GIBCO, Grand Island, N. Y.), to which sodium bicarbonate was added. Glycine was added only to the media used for sperm preservation. lon concentrations and osmolalities shown in table 1 are average values. In the Hanks' media sodium or chloride concentration varied as much as 15 p. 100 depending on the quantity of $\mathrm{HCl}$ or $\mathrm{NaOH}$ used to adjust the $\mathrm{pH}$. Polassium concentrations were constant within 1 or $2 \mathrm{mmol} / \mathrm{l}$.

For freezing sperm, two different diluents were used, a modified Poulik's triscitrate buffer with 10 p. 100 polyvinylpyrrolidone (PVP) and a modified Hanks' 2.6X, phosphate-buffered salt solution, with from 8-16 p. 100 dimethyl sulfoxide (DMSO) and from 0 to 16 p. 100 fetal calf serum (FCS). For incubating sperm, the Poulik's diluent proved most effective. For freezing eggs, the Hanks' double $(2 \mathrm{X})$ salt solution or the Hanks' $2.6 X$ diluent with 10 p. 100 PVP plus 8 p. 100 DMSO (pH 7.9) gave best results. Eggs were fertilized in the Hanks' (1X) salt solution (HSS).

Preparation of milt. - Between the time of collection and use for incubation or fertilization, milt was held in $20-30 \mathrm{ml}$ centrifuge tubes, covered with parafilm and stored on ice. Tubes were never filled more than $1 / 2$ to $3 / 4$ full.

Incubation of milt. - Successful sperm incubation depends on a combination of temperature, time, diluent composition and dilution. A 2-6 ml solution of milt plus diluents was gently mixed in a parafilm-covered, $20 \mathrm{ml}$ test tube and placed in a stationary water bath. Temperatures of $0,2-3,7-8$ and $10^{\circ} \mathrm{C}$ and incubation times of $1 / 4$ to $21 / 2 \mathrm{hrs}$ were tested. Although milt incubated for $21 / 2 \mathrm{hrs}$ at $10^{\circ} \mathrm{C}$ remained fertile, one 20-min. incubation or a combination of a 15 min. pre-thaw and a $15 \mathrm{~min}$. post-thaw incubation at $7-8^{\circ} \mathrm{C}$ was selected as optimal combinations for experimental efficiency and spermatozoan fertility. Milt was incubated in either Hanks' or Poulik's diluent before it was frozen. Some samples were used directly for insemination after freezing and thawing. Other samples were rediluted with Poulik's diluent 
Cryopreservation of gametes and embryos

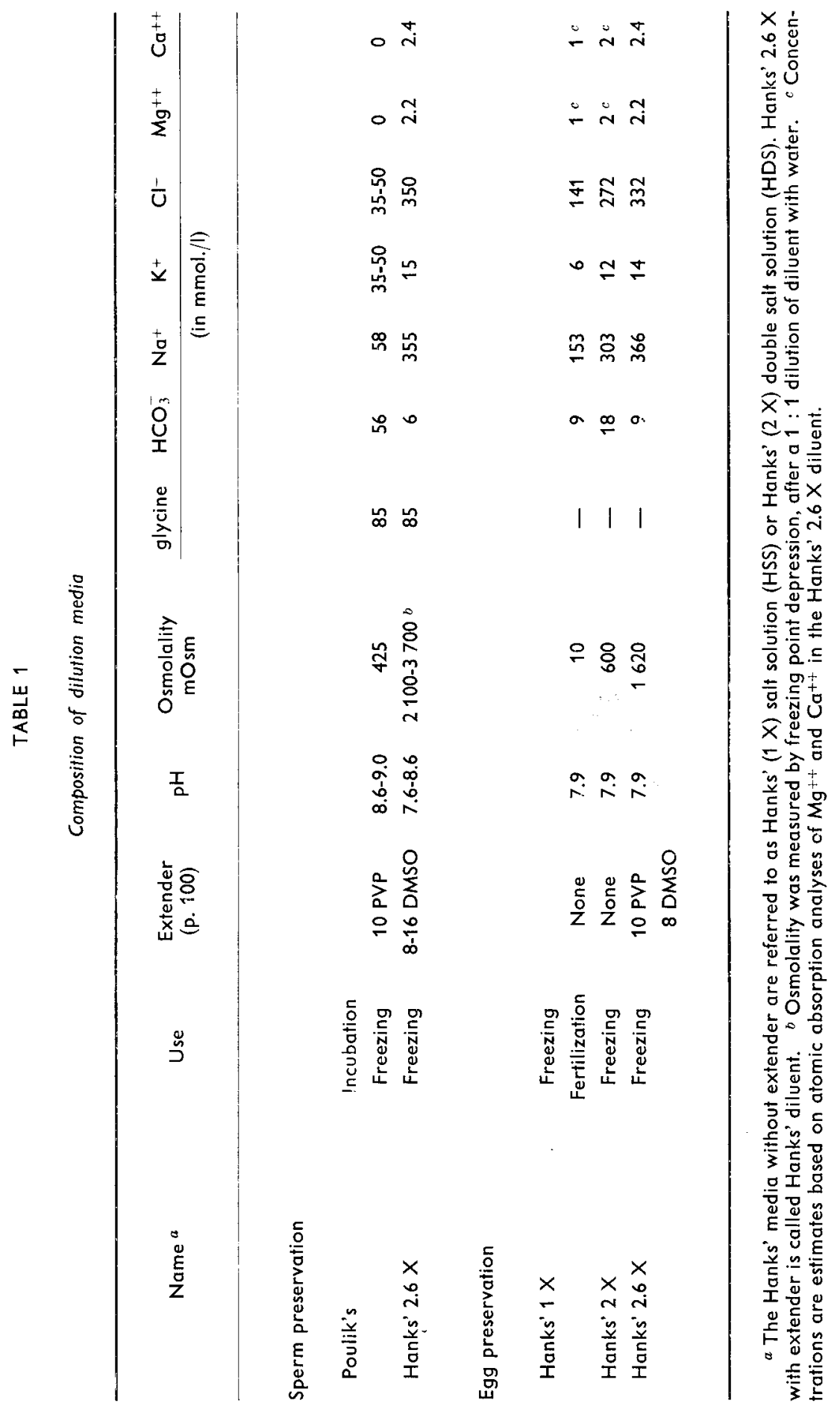


and re-incubated before insemination. After incubation in each diluent or in a combination of the two, fertility of unfrozen sperm was tested. In addition the effect of Poulik's diluent on the fertility of aging milt was tested with rainbow trout milt that had been stored undisturbed in sealed tubes at $0{ }^{\circ} \mathrm{C}$ for 2 days.

Freezing milt. - Diluted milt was frozen in plastic straws to various temperatures (i. e., $-6,-20$ or $-80^{\circ} \mathrm{C}$ ) at about $-5 \mathrm{C} / \mathrm{min}$. in a Linde biological freezer (BF-4-1). After reaching $-80^{\circ} \mathrm{C}$ in the Linde unit, samples to be frozen to $-196^{\circ} \mathrm{C}$ were placed in liquid $\mathrm{N}_{2}$. Since it was difficult to hold the samples at a constant temperature in the Linde chamber, samples were kept frozen only so long as their minimum temperature was constant (about 2 or $3 \mathrm{~min}$.) ; then they were thawed rapidly in 50-60 ${ }^{\circ} \mathrm{C}$ water. Some samples in liquid $\mathrm{N}_{2}$ were thawed shortly after freezing, while other samples were thawed after three or more days of storage. After they were thawed, sperm were either incubated in Poulik's diluent or used immediately for fertilization.

Vacuum drying milt. - Whole milt or milt diluted $1 / 2$ in Poulik's diluent 1.5 to $2 \mathrm{ml}$ total volume) cooled to $0^{\circ} \mathrm{C}$ was vacuum dried for about $45 \mathrm{~min}$. in $5 \mathrm{ml}$ vials fitted on the outside of a freeze-drying unit (Virtis, Model 10-010 with a maximum pump pressure of $1.10^{-4}$ torr $\mathrm{Hg}$ ). So long as drying continued, the vials stayed cold, but actual temperature of milt during the drying process was not measured. Vials were placed on ice while drying, so the samples did not warm above $0{ }^{\circ} \mathrm{C}$. Maximum vacuum, measured with a McCleod gauge was $0.2 \mathrm{~mm} \mathrm{Hg}$. In one experiment two freshly dried samples of whole rainbow trout milt were reconstituted with 1.5 to $2 \mathrm{ml}$ distilled water and immediately used to fertilize eggs. Other vials were stored at $+4^{\circ} \mathrm{C}$ or $-11^{\circ} \mathrm{C}$ for one year before being tested for fertility, at which time fresh samples were also dried.

Freezing eggs and embryos. - Unfertilized eggs, zygotes (eggs fertilized in HSS) and eyed eggs were frozen. They were frozen at various rates in several sizes of polyethylene vials in the Linde biological freezing unit to various temperatures between -5 and $-80^{\circ} \mathrm{C}$. In initial experiments survival after freezing to $-55^{\circ} \mathrm{C}$ was high but inconsistent, and no eggs survived after freezing to colder temperatures. Subsequently, in an attempt to identify and standardize the successful conditions, eggs were frozen only to temperatures between -5 and $-55^{\circ} \mathrm{C}$. Requirements for pre-freeze incubation of eggs has not been determined, but eggs were generally equilibrated for at least $15 \mathrm{~min}$. before freezing. Eggs were held at their minimum temperature in the Linde chamber for as long as their temperature could be kept constant, usually less than $5 \mathrm{~min}$. Then the frozen eggs were thawed slowly as the Linde chamber warmed. Thawing was completed at room temperature. Alternatively, eggs were thawed rapidly in hot $\left(40-60^{\circ} \mathrm{C}\right)$ water. None of the egg samples were stored after freezing.

\section{Results and discussion.}

Sperm preservation.

Incubation of fresh sperm. - Table 2 shows the results of incubating fresh, rainbow trout sperm in Hanks' and Poulik's diluents. Fertility after incubation corres- 
ponded to the osmolality and ionic strength of each solution. As the final osmolality of the incubation medium decreased, sperm fertility increased.

The higher DMSO concentration in the 1/4 dilution of milt in Hanks' (12 p. 100 DMSO) compared to that in the $1 / 2$ dilution ( 8 p. 100 DMSO) cannot account for the lower fertility of sperm in the $1 / 4$ dilution. In one experiment rainbow trout sperm were incubated after a $1 / 2$ or a 1/4 dilution in Hanks', and the final DMSO concentration in each solution was 6 p. 100. The relative fertility of sperm in the 2 dilutions was comparable to that in table 1.

Likewise a reduced concentration of undetermined, but critical components in the seminal plasma cannot explain the lower fertility of sperm in the $1 / 4$ dilution in Hanks'. (1) Sperm in the $1 / 8$ double dilution (first $1 / 2$ in Hanks' and then again $1 / 4$ in Pouliks) had a higher fertility than sperm in the $1 / 2$ dilution in Hanks' alone. (2) Sperm diluted $1 / 2$ or $1 / 4$ in Poulik's had a fertility equal to that of sperm in control, undiluted milt (table 2).

TABLE 2

Fertility of fresh rainbow trout sperm after incubation for $30 \mathrm{~min}$. at $0^{\circ} \mathrm{C}$

\begin{tabular}{lccc}
\hline Diluent & Dilution & No eggs & p. 100 eyed \\
\hline \multirow{2}{*}{ Hanks' } & & & \\
& $1 / 2$ & 722 & 37 \\
& $1 / 4$ & 1309 & 58 \\
Poulik's & $1 / 2$ & 1342 & 24 \\
& $1 / 4$ & 1183 & 98 \\
& $1 / 8$ & 1354 & 97 \\
Double & 1196 & 97 \\
Control & - & 943 & 64 \\
& - & 1296 & 68 \\
& & 1551 & 98 \\
\hline
\end{tabular}

Hanks' : 16 p. 100 DMSO, O FCS, pH 7.6. Poulik's : 10 p. 100 PVP, pH 8.6. Double : Milt diluted $1 / 2$ in Hanks' for 15 min. then rediluted $1 / 4$ in Poulik's for 15 min. Dilution refers to the milt (i.e., a $1 / 2$ dilution of milt results from a $1: 1$ mixture of milt and diluent).

The higher the $\mathrm{pH}$ of either Hanks' or Poulik's diluent, up to the highest $\mathrm{pH}$ used ( $\mathrm{pH} 8.9)$, the greater was the fertility of sperm after incubation. When incubated in a $1 / 2$ dilution of Hanks' diluent with $\mathrm{pH}$ of either 7.0 or 8.6 , sperm had a higher fertility in the $\mathrm{pH} 8.6$ solution (45 p. $100 \mathrm{compared}$ to $39 \mathrm{p} .100$ in the $\mathrm{pH} 7.9$ solution). However $\mathrm{pH}$ cannot be the primary factor responsible for the different fertility in the 2 diluents. When milt was incubated in a $1 / 2$ dilution of either Hanks' or Poulik's, each adjusted to $\mathrm{pH}$ 8.6, fertility in Hanks' was only 15 p. 100 compared to almost 70 p. 100 in Poulik's.

Incubation of aging sperm. - Table 3 shows the increased fertility of 2-day-old rainbow trout milt after incubation in Poulik's diluent. The diluent apparently has 
a restorative effect on sperm fertility and may be useful for short-term preservation of sperm without freezing.

TABLE 3

Fertility of fresh and 2-day-old rainbow trout sperm before and offer incubation in Poulik's diluent for $20 \mathrm{~min}$. at $8^{\circ} \mathrm{C}$

\begin{tabular}{lccccc}
\hline & \multicolumn{2}{c}{ Fresh milt } & & \multicolumn{2}{c}{ 2-day-old milt } \\
\cline { 2 - 3 } \cline { 5 - 6 } & No eggs & p. 100 eyed & & No eggs & P. 100 eyed \\
\cline { 5 - 6 } Unincubated & 847 & 84 & & 798 & 13 \\
Incubated & 658 & 78 & & 621 & 7 \\
& 534 & 87 & & 741 & 78 \\
& & & & 830 & 79 \\
\hline
\end{tabular}

Milt was diluted $1 / 2$ in Poulik's (10 p. 100 PVP; pH 8.9).

Freezing sperm. - Freezing sperm to various temperatures reveals the warmest freezing temperature at which fertility is lost. Table 4 shows the results of freezing brook trout sperm to $-6^{\circ} \mathrm{C}$ and Atlantic salmon sperm to $-8^{\circ} \mathrm{C}$. After being frozen to $-8^{\circ} \mathrm{C}$ in the Poulik's solution Atlantic salmon sperm had a fertility of 84 and 93 p. 100 compared to 96 p. 100 for control sperm.

TABLE 4

Fertility of sperm ofter «Freezing »

\begin{tabular}{|c|c|c|c|c|c|c|c|}
\hline & ${ }^{\circ} \mathrm{C}$ & Diluent & $\begin{array}{l}\text { Initial } \\
\text { dilution }\end{array}$ & $\begin{array}{l}\text { Post-thaw } \\
\text { incubation }\end{array}$ & $\begin{array}{c}\text { Final } \\
\text { dilution }\end{array}$ & No eggs & $\begin{array}{l}\text { p. } 100 \text { eggs } \\
\text { hatched }\end{array}$ \\
\hline \multirow[t]{7}{*}{ Brook trout } & & & & & & & \\
\hline & 0 & Control & - & - & - & 934 & 91 \\
\hline & & & - & 一 & - & 1031 & 94 \\
\hline & -6 & Poulik's & $1 / 2$ & + & $1 / 4$ & 253 & 51 \\
\hline & & Hanks' & $1 / 2$ & + & $1 / 4$ & 405 & 35 \\
\hline & & & $1 / 4$ & + & $1 / 8$ & 351 & 2 \\
\hline & & & $1 / 4$ & - & $1 / 4$ & 471 & $1 \overline{5}$ \\
\hline \multirow[t]{4}{*}{ Atlantic salmon } & & & & & & & \\
\hline & 0 & Control & - & - & - & 675 & 96 \\
\hline & -8 & Poulik's & $1 / 2$ & +- & $1 / 4$ & 484 & 84 \\
\hline & & & $1 / 2$ & + & $1 / 4$ & 506 & 93 \\
\hline
\end{tabular}

After initial dilution, incubate $15 \mathrm{~min}$. at $7.5^{\circ} \mathrm{C}$. Post-thaw incubation $15 \mathrm{~min} ., 7.5^{\circ} \mathrm{C}$ in Poulik's. Poulik's : 10 p. 100 PVP, pH 8.6 ; Hanks' for $1 / 2$ dilution of milt : 12 p. 100 DMSO, 12 p. 100 FCS, pH 7.6 ; Hanks' for $1 / 4$ dilution of milt ; 8 p. 100 DMSO, 8 p. 100 FCS, pH 7.6.

It is not known whether the sperm had completely frozen, but after a $1 / 4$ dilution of milt in Hanks' ( 3000 mOsm), the medium was approximately $2300 \mathrm{mOsm}$, which would freeze at $-1.24^{\circ} \mathrm{C}$. Note that fertility after freezing in Hanks' was better without a post-thaw dilution in Poulik's, even though the double dilution of incubated, unfro- 
zen sperm (table 2) increased sperm fertility. This suggests that the osmotic response of sperm that have been frozen to $-6^{\circ} \mathrm{C}$ in Hanks' differs from that of fresh, incubated sperm.

Fertility of sperm in Hanks' after freezing to - $20^{\circ} \mathrm{C}$ or lower has been unpredictable and low. In Poulik's, it has been completely lost. Perhaps the PVP in Poulik's is an unsatisfactory extender for salmonid spermatozoa at temperatures as low as $-20^{\circ} \mathrm{C}$, even though it was effective at $-8^{\circ} \mathrm{C}$. At the ultrastructural ievel sperm seemed intact after thawing from $-196^{\circ} \mathrm{C}$ in Hanks' (Summers and Gregory, 1974). In another experiment, rainbow trout sperm appeared motile after 7 months storage at $-196^{\circ} \mathrm{C}$ in Hanks'. They had not been fertile when thawed immediately after freezing. In one early study with extremely poor rainbow trout gamefes (control fertility was 0 and 0.2 p. 100) fertility after freezing to $-196^{\circ} \mathrm{C}$ in Hanks' without post-thaw incubation in Poulik's was 0 p. 100, but with the post-thaw dilution it was 6 and 4 p. 100. In this study, thawed sperm were diluted in Poulik's only after a delay of about $40 \mathrm{~min}$ at $0^{\circ} \mathrm{C}$. In an earlier study, without post-thaw incubation, fertility after freezing to $-196^{\circ} \mathrm{C}$ in Hanks', was 7 p. 100 compared to about 40 p. 100 for control, fresh milt.

TABLE 5

Ferfility of rainbow trout sperm after vacuum « drying» and storage

\begin{tabular}{|c|c|c|c|}
\hline Treatment & Storage $\left(0^{\circ} \mathrm{C}\right)$ & No eggs & p. 100 hatch \\
\hline $\begin{array}{c}\text { January, } 1974 \\
\text { Control } \\
\text { « Dried » } \\
\text { Undiluted } \\
\text { Undiluted }\end{array}$ & $\begin{array}{c}- \\
1 / 2 \text { hour } \\
1 \text { hour }\end{array}$ & $\begin{array}{l}1489 \\
1082 \\
1000 \text { * }\end{array}$ & $\begin{array}{r}70 \\
64 \\
0\end{array}$ \\
\hline & Storage $\left(-11^{\circ} \mathrm{C}\right)$ & No eggs & No eyed \\
\hline $\begin{array}{l}\text { April, } 1975 \\
\text { Control } \\
\text { Control } \\
\text { « Dried » } \\
\text { Undiluted } \\
\text { Undiluted } \\
\text { Undiluted } \\
\text { Diluted } \\
\text { Diluted } \\
\text { Undiluted } \\
\text { Undiluted } \\
\text { Undiluted } \\
\text { Diluted } \\
\text { Diluted } \\
\text { Undiluted }\end{array}$ & $\begin{array}{c}- \\
- \\
10 \text { hours } \\
1 \text { week } \\
1 \text { week } \\
1 \text { week } \\
1 \text { week } \\
11 \text { days } \\
2 \text { weeks } \\
2 \text { weeks } \\
2 \text { weeks } \\
2 \text { weeks } \\
1 \text { year }\end{array}$ & $\begin{array}{rl}1 & 192 \\
1 & 133 \\
1 & 204 \\
910 \\
917 \\
1039 \\
1333 \\
1718 \\
11481 \\
1807 \\
1676 \\
1 & 364 \\
1 & 854\end{array}$ & $\begin{array}{r}262 \\
181 \\
\\
20 \\
36 \\
17 \\
31 \\
41 \\
52 \\
7 \\
3 \\
22 \\
0 \\
11\end{array}$ \\
\hline
\end{tabular}

Milt was « dried » either undiluted or after a $1: 1$ dilution with Poulik's diluent ( $\mathrm{pH}$ 8.7). Extent of dehydration was not measured. In the April 1975 experiment 12 samples of "dried " diluted or undiluted milt, stored for from 10 hours to 2 weeks and 1 sample stored for 1 year had no fertility. A total of 8 eyed eggs resulted from three additional samples. * Number is an estimate. 
Clearly, for successful freezing below $-8^{\circ} \mathrm{C}$, several changes in the protocol are necessary. The following seem advisable : (1) use DMSO as the cryoprotectant in the modified Poulik's diluent, (2) gradually dilute the Hanks' diluent after thawing, thus reducing osmotic damage of (3) use a more physiological concentration of Hanks' for freezing protection.

Vacuum drying sperm. - Vacuum drying as an alternative to freezing would eliminate problems with storage at very low temperatures. There are reports of successful inseminations with freeze-dried sperm of rabbits (Yushchenko, 1960) and bulls (Meryman and Kafig, 1959, and Vandemark, 1961) and other reports of motility ofter « drying » sperm of bulls (Singh and Roy, 1966) and poultry (Polge et al., 1949). However the method has not been reproducible (Saacke and Almquist, 1961 and Sherman, 1963).

The results of vacuum drying rainbow trout sperm have also been unreproducible (table 5). In the first experiment, 64 p. 100 in one sample of eggs fertilized with reconstituted, «dried » sperm and 0 p. 100 in the other sample hatched. Milt in both samples looked dry and flaky, but no measurement or control of percentage dehydration and no control over the temperature reached by samples during drying was possible.

When the experiment was repeated in the spring of 1975 some samples were diluted with Poulik's diluent before drying. « Dried» undiluted milt formed clumps when reconstituted with water, but diluted milt dispersed readily after rehydration. The results shown in table 5 reveal little relationship between fertility and pre-drying dilution. The small number of eggs that eyed after insemination with « dried » sperm may reflect the poor quality of eggs. Only a small percentage of control eggs eyed and a smaller percentage hatched. Because of the egg quality and the inconsistent fertility of « dried » sperm, the results are presented as the number rather than the percentage eggs that eyed.

A few samples, including some with resultant fertility, contained visible moisture after storage with a dessicant in sealed containers at $-11^{\circ} \mathrm{C}$. Samples stored at $+4{ }^{\circ} \mathrm{C}$ for one year had decomposed. Although the amount of water removed was not measured and was not the same in separate samples, it is certain that the samples were not completely dry. However enough water had been removed to allow some survival of « dried » sperm after $6 \mathrm{hrs}$ in liquid $\mathrm{N}_{2}$, since in one experiment two eggs fertilized with such sperm had eyed.

Sample temperatures that were measured during drying varied. Minimum values ranged from -7 to $-35^{\circ} \mathrm{C}$. The freeze-drying equipment was modified in an attempt to control sample temperatures and thus control the rate of dehydration, but the changes were unsuccessful. In subsequent experiments sperm were structurally disrupted and the tails were often tangled. For lack of available equipment needed to control the rate and extent of sample dehydration, the experiments have been discontinued.

Although results show that vacuum-dried milt can be fertile, it is clear that the method needs significant modification and refinements before it can be a useful procedure. Perhaps freezing milt with a diluent to as low a temperature as practical before drying it, would eliminate the mechanical damage observed in the present 
experiments in which a vacuum was applied to unfrozen samples of milt. Reconstituting «dried » milt with more water than was removed during drying could activate sperm. Either an alternative to using water or a careful measurement of the quantity of water needed might improve retention of fertility after rehydration.

Egg and embryo preservation. - The data in table 6 represent the results of freezing unfertilized eggs, zygotes and eyed eggs (embryos) from one set of experiments with rainbow trout and book trout gametes. Unfertilized eggs, frozen to $-20^{\circ} \mathrm{C}$ were fertile after being thawed, and high percentages of zygotes or eyed eggs survived after being frozen to temperatures as low as $-50^{\circ} \mathrm{C}$. Adcitional experiments with Atlantic salmon and rainbow trout eggs have yielded similar results. So far the minimum temperature at which zygotes and eyed eggs have survived has been " $-55^{\circ} \mathrm{C}$ with gametes from Atlantic salmon.

TABLE 6

Hatching of eggs after freezing : no storage

\begin{tabular}{|c|c|c|c|c|c|c|}
\hline Species & $\begin{array}{c}\text { Stage } \\
\text { frozen }\end{array}$ & $\begin{array}{l}\text { Fertilization } \\
\text { medium }\end{array}$ & $\begin{array}{l}\text { Freezing } \\
\text { medium }\end{array}$ & $\begin{array}{l}\text { Minimum } \\
\text { temp. }{ }^{\circ} \mathrm{C}\end{array}$ & $\begin{array}{l}\text { No } \\
\text { eggs }\end{array}$ & $\begin{array}{l}\text { p. } 100 \\
\text { hatch }\end{array}$ \\
\hline Rainbow & $\begin{array}{l}\text { Unfert. } \\
\text { Zygote } \\
\text { Eyed } \\
\text { Eyed } \\
\text { Control } \\
\text { Control } \\
\text { Control } \\
\text { Zygote } \\
\text { Zygote } \\
\text { Control } \\
\text { Control } \\
\text { Control }\end{array}$ & $\begin{array}{c}\text { HSS } \\
\text { HSS } \\
\text { Water } \\
\text { Water } \\
\text { HSS } \\
\text { Water } \\
\text { Water } \\
\text { HSS } \\
\text { HSS } \\
\text { HSS } \\
\text { HSS } \\
\text { Water }\end{array}$ & $\begin{array}{c}\text { HSS } \\
\text { HSS } \\
\text { HSS } \\
\text { HSS } \\
- \\
- \\
\text { HSS } \\
\text { Hanks' } \\
- \\
-\end{array}$ & $\begin{aligned} &-20 \\
&- 20 \\
&-5 \\
&-20 \\
&+3 \text { to }+5 \\
&+3 \text { to }+5 \\
&+3 \text { to }+5 \\
&-50 \\
&-50 \\
&+3 \text { to }+5 \\
&+3 \text { to }+5 \\
&+3 \text { to }+5\end{aligned}$ & $\begin{array}{c}360 \\
370 \\
75 \\
75 \\
{ }^{643} \\
700 \\
750 \\
230 \\
505 \\
693 \\
862\end{array}$ & $\begin{array}{l}66 \\
68 \\
96 \\
39 \\
(75) * \\
74 \\
80 \\
20 \\
70 \\
80 \\
71 \\
87\end{array}$ \\
\hline
\end{tabular}

Control eggs; minimum temperature is approximate. * Sample had about 1000 eggs; An incubator accident shortly after eying destroyed majority of eggs. Most had eyed and about 75 p. 100 of few remaining eggs hatched. HSS : Hanks' $\left(\begin{array}{l}1 \\ X\end{array}\right)$ salt soln., Hanks' : diluent with 10 p. 100 PVP, 8 p. 100 DMSO.

After fertilization and before eying, the egg is especially delicate. Fortunately by fertilizing salmonid eggs in a salt solution that allows the sperm to enter the micropyle but prevents the elevation of the fertilization membrane, one can have a zygote that is physiologically like an unfertilized egg (Ginsburg, 1963). In several experiments, about 75-100 p. 100 of the control eggs that were fertilized in the Hanks' (1X) salt solution ( $\mathrm{pH} \mathrm{7.9)}$ hatched. A similar percentage of these eggs (zygotes) hatched after they were frozen to -5 or $-12{ }^{\circ} \mathrm{C}$.

Hatching of all eggs that were supercooled or frozen to -5 or $-12^{\circ} \mathrm{C}$ has been uniformly high. Survival after freezing to colder temperatures has been less consistent. The biggest technical difficulty has been controlling the optimal rate of cooling. A sudden release of the latent heat of fusion in a sample raises its temperature by as much as $15^{\circ} \mathrm{C}$ or more and causes a high mortality. It is probable that 
eggs surviving at -40 and $-55^{\circ} \mathrm{C}$ would have survived colder temperature as well, but the successful method of cooling has not been standardized adequately for testing survival at lower temperatures.

So far an initial freeze rate of about $3-5^{\circ} \mathrm{C} / \mathrm{min}$., followed by a somewhat faster rate below $-8^{\circ} \mathrm{C}$ has been most successful. Optimal thaw rate seems to depend on the freeze rate and perhaps also on the stage of development. Unfertilized eggs and zygotes have survived best with a slow thaw ; eyed eggs have done best with a rapid thaw. The techniques are still in a preliminary stage of development and storage of frozen eggs has not been tested. Methods are now being developed for controlling the release of latent heat during freezing and for storing the frozen samples at different temperatures.

Symposium sur la Reproduction des Poissons Paimpont, France, 19-21 septembre 1977.

Acknowledgments. - This work is a result of research sponsored in part by NOAA, Office of Sea Grant, Dept. of Commerce under Grant 04-7-158-44034.

Résumé. Après conservation pendant deux jours à l'état non dilué, du sperme de truite Arc-en-ciel Salmo gairdneri est mis en incubation dans un diluent Tris-citrate $(\mathrm{pH} \mathrm{8,9)}$; le pouvoir fécondant passe alors de 7 et 13 p. 100 à 78 et 79 p. 100 , atteignant le niveau initial du sperme frais. Du sperme de saumon atlantique Salmo salar congelé à $-8{ }^{\circ} \mathrm{C}$ conserve une fécondance de 84 à 94 p. 100 ; après conservation à $-196^{\circ} \mathrm{C}$; les spermatozoïdes retrouvrent leur motilité, mais non leur fécondance; ceci est vraisemblablement dô à la pression osmotique ef au cryoprotecteur des dilueurs. Des spermatozoïdes lyophylisés conservent leur pouvoir fécondant mais la méthode doit être améliorée. Des œufs pris immédiatement après insémination et des embryons au stade œillé survivent après passage à $-55^{\circ} \mathrm{C}$. Des ovules congelés à $-20^{\circ} \mathrm{C}$ ont pu être fécondés après décongélation.

\section{References}

BILLARD R., JALABERT B., 1974. L'insémination artificielle de la truite (Salmo gairdneri Richardson). Ann. Biol. anim. Bioch. Biophys., 14, 601-610.

BILLARD R., PETIT J., JALABERT B., SZÖLLÖSI D., 1974. Artificial insemination in trout using a sperm diluant, 715-723. In BLAXTER J. H. S., The early life history of fish, Springer Verlag, New York.

BLAXTER J. H. S., 1953. Sperm storage and cross-fertilization of spring and autumn spawning herring. Nature, 172, 1189-1190.

GINSBURG A. S., 1963. Sperm-egg association and its relationship to the activation of the egg in salmonid fishes. J. Embryol. exp. Morph., 11, 13-33.

HODGINS H. O., RIDGWAY G. J., 1964. Recovery of viable salmon spermatozoa after fast-freezing. Progr. Fish-Cult., 26, 95.

HOYLE R. J., IDLER D. R., 1968. Preliminary results in the fertilization of eggs with frozen sperm of Atlantic salmon (Salmo salar). J. Fish. Res. Bd. Canada, 25, 1295-1297.

LEIBO S. P., 1977. Preservation of mammalian cells and embryos by freezing, 311-334. In SIMATOS D., STRONG D. M., TURC J. M., Cryoimmunologie, Colloq. INSERM, vol. 62.

MERYMAN H. T., KAFIG E., 1959. Survival of spermatozoa following drying. Nature, 184, 470-471.

OTT A. G., HORTON H. F., 1971. Fertilization of steelhead trout (Salmo gairdneri) eggs with cryopreserved sperm. J. Fish. Res. Bd. Canada, 28, 1915-1918.

POLGE C., SMITH A. U., PARKES A. S., 1949. Revival of spermatozoa after vitrification and dehydration at low temperatures. Nalure, 164, 666.

SAACKE R. G., ALMQUIST J. O., 1961. Freeze-drying of bovine spermatozoa. Nature, 192, 995-996. 
SHERMAN J. K., 1963. Improved methods of preservation of human spermatozoa by freezing and freeze-drying. Fertil. Steril., 14, 49-64.

SINGH S. G., ROY D. J., 1966. Freeze-drying of bovine semen. Indian J. vet. Sci., 37, 1-7.

SUMMERS R. G., GREGORY R. W., 1974. Completion report on cryopreservation and fertilization capacity of Atlantic salmon sperm. Contract No. 14-16-0008-1116, 23 p. mimeo.

SZÖLLÖSI D., BILLARD R., 1974. The micropyle of trout eggs and its reaction to different incubation media. J. Microscop., 21, 55-62.

VANDEMARK N. L., 1961. Preservation of animal breeding stocks through storage of germ plasm. Publ. amer. Assoc. Adv. Sci., 66, 337-354.

WHITTINGHAM D. C., LEIBO S. P., MAZUR P., 1972. Survival of mouse embryos frozen to - 196 and $-269^{\circ} \mathrm{C}$. Nature, 236, 411-414.

YUSHCHENKO N., 1960. Freeze drying in the preservation of animal semen. Referat. Zhur. Biol. No 25943 (translation).

ZELL S. R., 1974. Completion Report. Contract No. 14-16-0008-813, U. S. Bureau Sport Fisheries and Wildlife. The Biochemistry of solute and ion exchange from Atlantic salmon sperm cells during cryopreservation. 27 p. mimeo. 